\title{
Nalar 'Irfānī: Tradisi Pembentukan dan Karakteristiknya
}

\author{
Zainal Abidin \\ IAIN Metro \\ Email: zainaiabidin@metrouniv.ac.id
}

\begin{abstract}
It must be acknowledged that the Islamic world until these days has left far behind from the West in terms of achievement in science and technology as a result of a burhàni-based system of knowledge that is rational-empirical. Therefore, Muslims must take back a burhani tradition that was once victorious in the golden age of Islam in the past. But the West that has been advanced with its civilization "stabbed" and "killed" the civilization they had built themselves. This is due to the fact that the standard of truth is based on the arrogance and supremacy of the rational-empirical reasoning as such, while bayanin (textual) and 'irfānì (spiritual) reasonings are alienated or marginalized, although it is clear that human life cannot be be measured only on the criteria of empirical rationalism, but it needs textual and spiritual approaches.

Keywords: Nalar 'Irfānī, Tradition of formation, characteristics
\end{abstract}

\section{A. Pendahuluan}

Banyak pemikir Islam mensinyalir telah terjadi suatu keterputusan epistemologis (epistemological break) dalam sistem epistemologi ilmu-ilmu keislaman. Keterputusan epistemologi tersebut telah menandai dan berdampak pada sebuah pergeseran paradigma (shift paradigm) dalam ranah pemikiran Islam.

Salah seorang filosof Islam kontemporer yang berasal dari wilayah Magribi atau yang dikenal sekarang dengan Maroko, yakni Muhammad 'Abid al-Jabiri menyinggung adanya suatu fakta demikian. Bahkan, ia menegaskan keterputusan epistemologi itu dalam tiga klasifikasi, yaitu epistemologi bayānī̄ 'irfānī, dan burhānī.

Dalam skema geo-keilmuan atau kawasan persemaian dan berkembangnya suatu epistemologi atau sistem pembentuk nalar, dua terma di atas yakni bayānī dan 'irfānī adalah sistem pengetahuan yang dominan berkembang di wilayah Timur (Masyriq), sedangkan terma terakhir, yakni burhānī adalah sistem pengetahuan yang dominan berkembang di wilayah Barat (Maghrib). ${ }^{1}$

Sejarah telah mencatat ketiga sistem pengetahuan yang melahirkan sistem nalar dan budaya itu sebenarnya sudah dan sedang atau barangkali akan terus dipraktekkan oleh umat Islam maupun umat yang lainnya dengan tingkat intensitas yang berbeda-beda dalam domain pemakaiannya beserta kelebihan dan kekurangannya masing-masing sesuai dengan perkembangan zaman.

Untuk saat ini harus diakui, dunia Islam jauh tertinggal dari Barat dalam capaian ilmu pengetahuan dan teknologi sebagai hasil dari sistem pengetahuan burhānī yang bersifat rasional-empiris. Kritik dari al-Jabiri sendiri adalah, bahwa umat Islam saat ini, harus menjemput kembali tradisi burhānī yang pernah jaya dalam masa keemasan Islam masa lalu. Ia juga mewanti-wanti agar umat Islam

${ }^{1}$ Muhammad 'Abid al-Jabiri, Takwin al-'Aql al-'Arabi, (Beirut: Markaz as-Saqafi al-'Arabi, 1991), h. 56 
tidak terlalu "larut" dalam sistem pengetahuan bayānī dan 'irfānī yang mendominasi dunia Islam pascaberakhirnya kejayaan Islam seiring bangkitnya Barat.

Namun, perlu diingat bahwa Barat yang maju saat ini dengan peradaban yang dihasilkan justru "menikam" dan "membunuh" peradaban yang mereka buat sendiri. Hal tersebut disebabkan karena ukuran kebenaran didasarkan pada bentuk arogansi dari supremasi nalar rasional-empiris an sich, sementara nalar bayānī (tekstual) dan nalar 'irfānī (spritual) menjadi teralienasi atau dikesampingkan, padahal sudah dimaklumi bahwa kehidupan manusia, tidak bisa hanya diukur berdasarkan pada kriteria rasionalisme-empirisisme, namun perlu juga dipadukan dengan pendekatan tekstual dan spritual. Artinya, dalam konteks ini tidak adil menyandarkan pada sistem pengetahuan burhani an sich, tetapi, perlu juga diintegrasikan dengan sistem pengetahuan bayānī dan 'irfānī.

Khusus untuk nalar yang terakhir (baca: 'irfani) nampaknya perlu mendapat apresiasi dan penelaahan lebih lanjut lebih dalam lagi. Sebab, watak dan karakteritik sistem epistemologi 'irfani ini yang dipahami bernuansa esoterik atau bersifat spritual dalam memandang realitas justru mempunyai momentum untuk dikembangkan. Lebih-lebih lagi dewasa ini kecenderungan dunia melalui sistem pengetahuan dan teknologi yang berkembang telah banyak menafikan unsur-unsur 'irfani atau spritual tersebut. Padahal bisa disaksikan betapa era moderen dengan logika positivistiknya yang mendewakan rasionalisme dan empirisisme telah dianggap "gagal" melahirkan kepuasaan dan kebermaknaan hidup manusia modern.

\section{B. Pembahasan}

\section{Tradisi ‘Irfān̄i Dan Pembentukannya}

Sebelum membahas pengertian dan pembentukan nalar 'irfānī dalam konstelasi sistem pengetahuan Islam, ada baiknya dapat diperhatikan realitas geo-politik saat terjadinya mata rantai yang mendeterminasikan setiap gerak keilmuan dalam ranah kepentingan dan kuasa dalam membentuk sistem pengetahuan tersebut.

Dalam kenyataan sejarah, perkembangan sistem pengetahuan yang terjadi dalam pemetaan wilayah Maghrib dan Masyriq sebagaimana yang dilakukan oleh al-Jabiri, tentu saja bukan sebuah kebetulan, melainkan harus dibaca dalam suatu asumsi adanya faktor tertentu dalam percaturan relasi kuasa dan pengetahuan. Hal ini bisa dibuktikan bahwa pada era kodifikasi (tadwin) abad ke $2 \mathrm{H}$, terdapat tiga kekuatan ideologis-politis yang saling bertarung.

Pertama, adalah kekhalifahan Abbasiah dengan Baghdad sebagai ibu kotanya. Dalam bidang ideologi, khalifah menginstruksikan untuk menganut ideologi Sunni yang dominan dalam pemakaian sistem pengetahuan bayani, dengan maraknya dominasi pengetahuan kalam dan fiqih. Walaupun masa alMa'mun dan khalifah sesudahnya agak bergeser orientasi paradigma 
epistemologis ke arah nalar burhani, namun dalam waktu yang tidak lama kembali lagi pada sistem pengetahuan bayani seperti sebelumnya. ${ }^{2}$

Kedua, kekuasaan Syi'ah yang direpresentasikan secara politis oleh Dinasti Bani 'Ubayd (Fatimi) di Mesir dan diwakili secara sosial oleh para propagandis Syi'ah Isma'iliyah di Asia Tengah. Dalam membangun rumusan ideologi, dinasti ini banyak mengadopsi ajaran-ajaran Hermetisme/NeoPlatonisme untuk kepentingan mereka dalam mendukung tesis-tesis politik tentang kemaksuman imam sehingga dominan membentuk nalar atau sistem pengetahuan 'irfani.

Ketiga, bangkitnya kekhalifahan Mu'awiyah II di Andalusia, yang secara politik berhadapan dengan dua penjuru "musuh" kekuasaan di atas dengan ideologi dan nalarnya masing-masing. Logis kiranya dalam latar belakang seperti itu, pihak sayap politik Islam di Barat ini mengembangkan suatu ideologi dan sistem pengetahuan atau nalar yang berbeda dari dua kekuasaan di atas, yakni berkembangnya sistem pengetahuan burhani yang kemudian mengilhami kebangkitan Barat. ${ }^{3}$

Kata 'irfani berasal dari akar kata bahasa arab 'arafa yang sinonim dengan kata ma'rifah, yang bermakna suatu pengetahuan.4 'lrfan atau makrifat berkaitan dengan pengetahuan yang diperoleh secara langsung lewat pengalaman. Hal ini berbeda dengan istilah atau konsep ilmu yang diperoleh melalui usaha (kasb) pencarian dari transformasi (naql) atau penalaran rasio (aql).

Dari sini dapat diambil perstilahan, bahwa 'irfani adalah suatu pengetahuan yang diperoleh melalui pencapaian dan penyinaran hakekat oleh Tuhan kepada hamba yang menjalani (salik) sehingga terbuka hakekat tersebut (kasyf) melalui jalur olah rohani atau laku-jiwa yang didasarkan atas nama cinta (mahabbah). ${ }^{5}$

Tradisi 'irfani pada dasarnya bersumber dari dalam Islam sendiri. ${ }^{6}$ Sebab, pada dasarnya Islam dalam ajarannya, terdapat suatu dimensi yang mengandung unsur zahir yang mengambil pola pada ajaran syari'at dan ada dimensi lainnya yang mengandung unsur batin yang mengambil pola aspek hakikat. Unsur hakikat inilah yang membentuk nalar 'irfani atau gnostik. Di samping bersumber dari Islam sendiri, menurut J. S. Tirmingham, tradisi spiritualitas Islam atau 'irfani juga mendapat pengaruh dari tradisi dan

2 Muhammad 'Abid al-Jabiri, Post Tradisionalisme Islam, alih bahasa Ahmad Baso, Yogyakarta: LKiS, h. 94.

${ }^{3}$ Muhammad 'Abid al-Jabiri, Takwin 'Aql al-'Arabi, h. 223.

${ }^{4}$ Muhammad 'Abid al-Jabiri, Bunyah al-'Aql al-'Arabi, (Beirut: Al-Markaz asSaqafi al-'Arabi, 1993), h. 251.

5 Mehdi Ha'iri Yazdi, Ilmu Hudhuri: Prinsip-prinsip Epistemologi dalam Filsafat Islam, alih bahasa Ahsin Muhammad, (Bandung: Mizan, 1994), h. 47.

${ }^{6}$ Lihat perdebatan tentang asal-usul 'irfani atau tasawuf Islam dalam uraian R.A. Nicholson, Mistik dalam Islam, alih bahasa Tim Penerjemah Bumi Aksara, (Jakarta: Bumi Aksara, 1998), h. 8.

| RI'AYAH, Vol. 4 No. 01 Januari-Juni 2019 
kebudayaan lain waktu itu yang kemudian turut memperkaya sistem 'irfani tersebut. ${ }^{7}$

Kenyataan keterpengaruhan suatu konsep atau pemikiran di atas pada dasarnya bisa dimaklumi. Sebab, dalam sejarah perkembangan ilmu pengetahuan bisa terjadi suatu tingkat keberlangsungan (contiunity) dan perubahan (change) dalam keilmuan, termasuk tentunya tradisi 'irfani ini dalam proses pembentukannya.

\section{Karakteristik Nalar 'Irfani}

Dalam arti lain pembedaan nalar 'irfani dengan nalar yang lain dalam proses dan metodenya bisa dilihat bahwa, nalar 'irfani berkaitan dengan hati (qalb) karena wilayah bekerjanya pada dimensi batin. Nalar 'irfani dapat menangkap objeknya secara langsung. Adapun objek yang ditangkap nalar 'irfani bersifat lebih abstrak; seperti rasa cinta, benci, kecewa, dan bahagia. ${ }^{8}$

Pengetahuan 'irfani tidak didasarkan atas teks seperti bayani, tetapi pada kasyf, di mana dialaminya suatu pengalaman ketersingkapan rahasia-rahasia realitas oleh Tuhan. Sumber dari nalar 'irfani adalah realitas pengalaman (experience) yang ditemukan langsung oleh sang arif atau sufi sebagai kelompok pendukung keilmuan dalam sistem nalar ini. Karena itu, pengetahuan 'irfani tidak diperoleh berdasarkan analisis teks dan pembuktian empiris, tetapi dengan olah ruhani, ${ }^{9}$ di mana dengan kesucian hati, diharapkan Tuhan akan melimpahkan (faidh) pengetahuan langsung kepadanya.

Dengan demikian, telah jelas bahwa kekhasan nalar 'irfani ini terletak pada sifatnya yang langsung. Mengenai karakter dari sifat langsung 'irfani dalam menangkap objeknya ini kemudian dapat dianalisis ke dalam beberapa hal; Pertama, pengetahuan 'irfani bisa dicapai melalui pengalaman, yaitu dengan mengalami atau merasakan sendiri objeknya. Oleh karena itu, nalar 'irfani dilihat dari sudut ini, disebut dzauqi (rasa), dan bukan melalui penalaran, seperti yang dilakukan oleh nalar burhani. MisaInya, kita tidak akan mengetahui atau memahami "cinta" semata dengan membaca literatur tentang cinta, tetapi kita mengenal cinta tersebut dengan mengalaminya.

Tanpa pengalaman tersebut, kita tidak akan pernah mengerti dan memahami apa dan bagaimana hakikat sebuah cinta. Cinta tak bisa dipahami lewat akal, tetapi lewat hati (intuisi). Maka tidak heran kadang-kadang kita tidak mampu mengungkapkan rasa cinta itu dengan kata-kata atau secara diskursif karena ia bukan lah wilayah akal. Namun berbeda halnya dengan hati yang bisa memahami hakikat cinta lewat pengalaman, bukan lewat kata-kata atau definisi.

Dengan demikian, kita pada dasarnya tidak akan bisa mengerti bagaimana keadaan cinta seorang sufi terhadap Tuhannya, tanpa kita sendiri

\footnotetext{
1971), h. 2.

${ }^{8}$ Mulyadhi Kartanegara, Menyibak Tirai Kejahilan:

Pengantar Epistemologi Islam, (Bandung: Mizan, 2003), h. 59.

${ }^{9}$ M. Amin Abdullah, Islamic Studies di Perguruan Tinggi: Pendekatan IntegratifInterkonektif, (Yogyakarta: Pustaka Pelajar, 2005), h. 208.
}

${ }^{7}$ J. S. Tirmingham, The Sufi Orders in Islam, (London: Oxford University Press,

| RI'AYAH, Vol. 4 No. 01 Januari-Juni 2019 
berupaya membangun hubungan untuk bisa jatuh cinta kepada-Nya. ${ }^{10}$ Konsep cinta seorang hamba terhadap Khaliq-nya itulah yang di dalam disiplin sufistik banyak dikemukakan dan dirumuskan oleh berbagai macam aliran dan tarekat.

Kedua, sifat langsung pengetahuan 'irfani bisa diliihat dari apa yang sering disebut sebagai 'ilmu hudhuri. Pengetahuan 'irfani ditandai oleh hadirnya (hudhur) objek di dalam diri si subjek. Barangkali karena itu, pengetahuan ini disebut "presensial". Berbeda dengan pengenalan rasional yang memahami objek-objeknya lewat simbol-simbol/kata-kata, kalimat, atau rumus-rumus. Pengenalan 'irfani melampaui segala bentuk simbol dan menembus sampai ke dalam jantung objeknya.

Ketiga, sifat kelangsungan nalar 'irfani ini dapat dilihat dari apa yang disebut sebagai pengalaman "eksistensial". Akal dan metode rasionalnya menurut Muhammad Iqbal dan Henry Bergson, cenderung meruang-ruangkan (spatilize) objeknya dan mengukurnya dengan ukuran-ukuran atau standar yang homogen. Kecenderungan akal untuk menghomogenkan objek-objeknya ini membuat akal sering melakukan generalisasi sehingga sering mengabaikan partikularisasi objek-objeknya yang unik dan berdimensi variatif.

Selain itu, kita tahu dari pembahasan tentang 'irfani bahwa pengenalan rasional atau burhani dilakukan melalui kategori-kategori, seperti kategori ruang, waktu, dan kausalitas. Maka tidak mengherankan, oleh sebab itu, akal cenderung menggeneralisasi dengan mengkategorikan objek-objeknya. Sementara itu, kita tahu bahwa setiap pengkategorian atau pengklasifikasian selalu mengabaikan yang partikular, yang khusus, dan yang unik.

Berbeda dengan kecenderungan akal di atas, nalar 'irfani mengenal objeknya bukan melalui kategorisasi, melainkan mengenalnya secara intim kasus per kasus. Pengenalan intuisi seperti ini membuat pengenalan 'irfani lebih akurat dan langsung menyentuh objek-objek partikular dengan segala karakteristik dan keunikannya. Ambillah sebuah contoh, menurut kategori akal satu jam di mana pun akan sama saja kualitasnya. Demikian juga satu meter di sini akan sama saja dengan satu meter di mana pun juga seseorang berada di muka bumi ini. Pengenalan kategori akal akan mengabaikan kenyataan bahwa satu jam bagi yang ditunggu tidak akan sama bagi yang menunggu. Sebab bagi pihak yang ditunggu satu jam akan terasa berlalu begitu cepat, sedangkan bagi pihak yang menunggu akan terasa bergerak lamban sekali bahkan terkesan membosankan.

Sebaliknya, 'irfani yang beroperasi secara langsung pada objek-objek partikular akan mengerti keunikan-keunikan setiap ruang atau peristiwa dalam pengalaman eksistensial. Dengan metode yang sama, 'irfani mengerti mengapa bagi orang orang tertentu (khususnya orang orang yang beragama) mengenal dan percaya ada tempat-tempat yang sakral, suci, atau tempat yang dianggap keramat, sebagaimana juga ada waktu-waktu (hari, bulan, dan tahun) yang suci atau magis.

Oleh karena itu, untuk mengembangkan kecakapan nalar 'irfani, seperti yang diamalkan pada sebuah tarekat, seorang murid tidak diajak berdiskusi atau disuruh membaca setumpuk buku. Bagi para sufi, tasawuf tidak bisa hanya

${ }^{10}$ Ibid.

| RI'AYAH, Vol. 4 No. 01 Januari-Juni 2019 
dipahami lewat buku/kitab, tetapi dengan melakukan praktik langsung (suluk/riyadhah).

Untuk menggambarkan pernyataan di atas, ada baiknya diperhatikan suatu ungkapan sufistik dari Imam Jalaluddin ar-Rumi, sebagaimana dikutip oleh Mulyadhi Kartanegara, di mana Rumi pernah berkata, "Kalau Anda ingin mengetahui api secara 'irfani, panggang diri Anda di atas api".11 Artinya adalah, mengetahui suatu keadaan faktual atau eksistensial tentang panasnya api, bukan dengan membaca literatur tentang api. Demikian juga ditamsilkan, kalau Anda ingin mengenal apa itu manis, tak usah membaca keterangannya lewat buku, tetapi reguklah secangkir teh atau minuman yang manis, maka Anda akan mengerti manis secara langsung tanpa membutuhkan definisi. Kalau Anda ingin mengerti cinta, berusahalah jatuh cinta, begitu seterusnya dengan berbagai perumpamaan-perumpamaan semisal lainnya.

Secara umum, seorang murid biasanya diajak berzikir dalam bentuk mengulang-ulang nama-nama tertentu Tuhan. Zikir ini dilakukan sebagai cara mendekatkan diri kepada Tuhan karena dengan berzikir yang intensif, tulus, dan berulang-ulang, akan terjadi hubungan timbal-balik antara sang hamba dengan Khalik-nya. Karena menurut keyakinan para sufi, setiap pengucapan nama Tuhan akan mendapat balasan yang lebih intens dari Tuhan. Akibat yang diharapkan dari hubungan ini adalah terjadinya cinta timbal-balik di antara keduanya.

Selain melalui praktik langsung di lapangan dalam menggali pengalaman lebih bayak lagi, kecakapan nalar 'irfani perlu dibina melalui pembersihan jiwa atau dikenal dengan tazkiyah an-nafs. Karena sistem nalar 'irfani adalah rekonstruksi aspek kebersihan batiniah, maka proses pencapaiannya melalui metode yang dijalani adalah melalui proses maqamat14 dan ahwal15 dalam terminologi tasawuf.

Masih berkaitan dengan upaya tazkiyah an-nafs sebagai awal dari proses pendekatan diri kepada Tuhan, maka tepat melukiskannya dengan meminjam ungkapan Rumi lagi, sebagaimana dikutip kembali oleh Mulyadhi Kartanegara, bahwa "Kalau Anda ingin melintasi simbol dan huruf (dalam capaian ilmu dan makrifat), bersihkan dulu diri Anda dari segala debu ke-egoisan. Anda akan memperoleh pengetahuan para nabi, tanpa buku, tanpa guru."

Tugas manusia menurut para sufi adalah membersihkan jendela kaca hatinya. Selanjytnya, menunggu saat yang tepat untuk datangnya cahaya (nur) kebenaran memberkas di atasnya, dan diharapkan Tuhan sudi kiranya memberikan cahaya ke dalam hati sang hamba secara langsung tanpa perantara (bila wasithah). Dengan demikian, akan diperoleh pengetahuan yang benar dan meyakinkan. Dengan cara seperti itulah para sufi atau wali, dan bahkan nabi di puncaknya memperoleh pengetahuan langsung dari Sang Kebenaran (AI-Haqq)

${ }^{11}$ Mulyadhi Kartanegara, Renungan Mistik Jalaluddin Rumi, (Jakarta: Pustaka Jaya, 1987), h. 35.

| RI'AYAH, Vol. 4 No. 01 Januari-Juni 2019 
itu sendiri tanpa perantara apa pun. Dengan alasan ini, pengenalan langsung ini disebut 'ilmu ladunni. ${ }^{12}$

\section{Simpulan}

Dari pemaparan dan analisis kecil di atas dapat ditarik kesimpulan bahwa Nalar 'irfani ini dikembangkan tidak hanya oleh para sufi, tetapi juga oleh para filosof, seperti yang tecermin dari karya agung seorang filosof kontemporer Iran, Mehdi Ha'iri Yazdi. Ia mencoba menunjukkan bahwa Nalar 'irfani sebagai nalar spritualitas Islam sesungguhnya dalam konteks sekarang punya momentum yang tepat untuk dikembangkan. Tentu saja dengan upaya interpretasi dan rekonstruksi yang tepat dan baik terlebih dahulu dalam upaya penggalian khazanah 'irfani Islam, yang dalam sejarah perjalanannya banyak mengalami perdebatan dan image yang terkadang disalahpahami.

Momentum itu dipandang tepat, karena penggunaan nalar epistemologi lain (bayani dan burhani) yang dikembangkan dengan segala kelebihannya pada saat ini juga tidak dapat memuaskan, bahkan menyebabkan terjadinya krisis. Nalar 'irfani yang bergerak dalam aspek batiniah dengan landasan kepekaan spritualitas dan nurani yang sangat halus bertujuan membentuk karakter kemanusiaan dan ketuhanan seseorang, dinilai mempunyai suatu kontribusi yang cukup strategis dalam menyempurnakan dua sistem epistemologi lainnya; bayani dan burhani tersebut.

\section{Daftar Pustaka}

Muhammad 'Abid al-Jabiri, Takwin al-'Aql al-'Arabi, (Beirut: Markaz as-Saqafi al-'Arabi, 1991)

Muhammad 'Abid al-Jabiri, Post Tradisionalisme Islam, alih bahasa Ahmad Baso, Yogyakarta: LKiS

Muhammad 'Abid al-Jabiri, Bunyah al-'Aql al-'Arabi, (Beirut: Al-Markaz asSaqafi al-'Arabi, 1993)

Mehdi Ha'iri Yazdi, Ilmu Hudhuri: Prinsip-prinsip Epistemologi dalam Filsafat Islam, alih bahasa Ahsin Muhammad, (Bandung: Mizan, 1994)

Lihat perdebatan tentang asal-usul 'irfani atau tasawuf Islam dalam uraian R.A. Nicholson, Mistik dalam Islam, alih bahasa Tim Penerjemah Bumi Aksara, (Jakarta: Bumi Aksara, 1998)

J. S. Tirmingham, The Sufi Orders in Islam, (London: Oxford University Press, 1971)

MulyadhiKartanegara, Menyibak Tirai Kejahilan: Pengantar Epistemologi Islam, (Bandung: Mizan, 2003)

M. Amin Abdullah, Islamic Studies di Perguruan Tinggi: Pendekatan IntegratifInterkonektif, (Yogyakarta: Pustaka Pelajar, 2005)

Mulyadhi Kartanegara, Renungan Mistik Jalaluddin Rumi, (Jakarta: Pustaka Jaya, 1987)

${ }^{12}$ Musa Asy'ari, Filsafat Islam Sunnah Nabi dalam Berpikir, (Yogyakarta: LESFI, 1999), h. 68.

| RI'AYAH, Vol. 4 No. 01 Januari-Juni 2019 
Musa Asy'ari, Filsafat Islam Sunnah Nabi dalam Berpikir, (Yogyakarta: LESFI, 1999)

| RI'AYAH, Vol. 4 No. 01 Januari-Juni 2019 